\title{
TGFA Gene Product
}

National Cancer Institute

\section{Source}

National Cancer Institute. T GFA Gene Product. NCI Thesaurus. Code C118439.

A protein encoded by the TGFA gene. 